\title{
Examining the Link Between Information Technology Utilization, Work-Family Conflict, Commitment and Employee Performance
}

\author{
Akmal Maulidina ${ }^{1}$, Zainur Hidayah ${ }^{1}$, Anita Maharani2** \\ ${ }^{1}$ Master of Management Program, Postgraduate Program, Universitas Terbuka, Jakarta, Indonesia \\ ${ }^{2}$ Master of Management Program, Bina Nusantara University, Jakarta, Indonesia \\ *corresponding author e-mail : anita.maharani@binus.edu
}

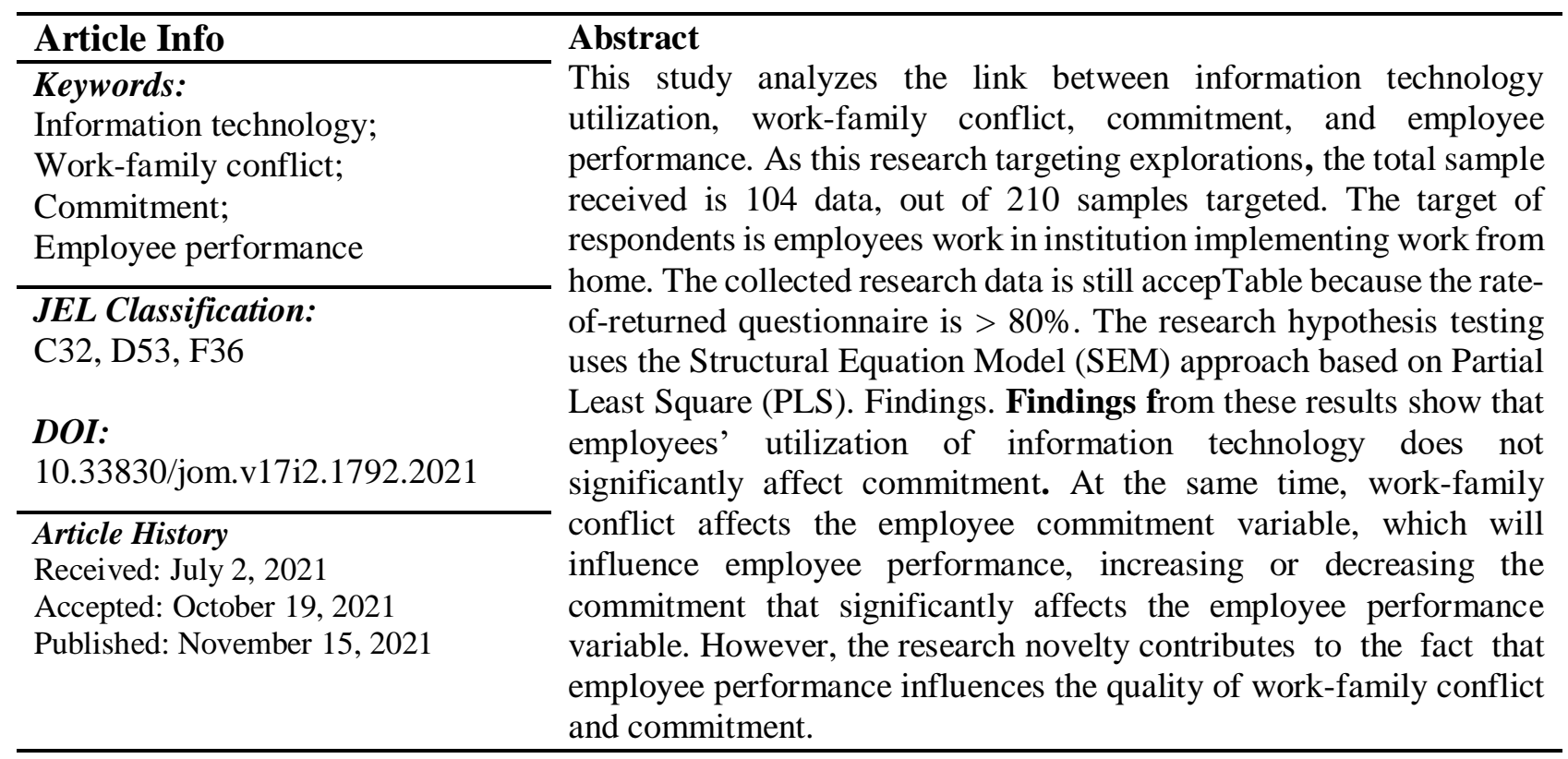

\section{Introduction}

Organizations pay attention to the performance of their employees, and even the organization will try to encourage employees to have optimal performance because organizational success is the output of their employees' performance. Siddiqui (2014) argues that one thing that can make employees have high performance is to provide full support to employees and in any form (Siddiqui, 2014). Forms of organizational support for employees, one of which is by providing work support facilities. The most common is information technology facilities so that organizations do not hesitate to make particular investments for information technology as part of organizational activities (Dewett \& Jones, 2001). Thus the organization will strive to encourage the performance of its employees through investing in information technology and aimed at supporting employees.

The conditions described above occur during regular times. The world, rocked by a pandemic at the end of 2019, triggered the countries' governments to take action. Since the pandemic was declared a national disaster and the Indonesian government recommended that organizations adjust company management policies, many organizations have shifted their employees from working for companies to homes. In the form of all employees working from home, the policies carried out by this organization known as Work From Home or WFH. There is no specific information that states when implementing WFH practice. However, an organization 
called the Law Office in the United States named Seyfarth surveyed its clients on March 12 to 16, 2020, and received a response of 550 organizations, of which the majority of organizations became respondents encourage their employees to work from home or WFH, on responses to phenomena that occur during the data collection period (Zeidner, 2020). To make the WFH policy successful, the organization provides a series of supporting facilities, including work facilities at home, including the internet. Due to the existence of WFH, there is an increase in internet use, which is considered quite significant, based on data from the Indonesian Internet Service Providers Association (APJII), which released information on an increase in internet use by 73.7 percent or the equivalent of 196.7 million internet users (with a total population Indonesia as many as 266.9 million people according to the Central Bureau of Statistics.

It is exciting to highlight the performance impacted by implementing WFH, considering the changes in habits that occur in the organization. One of the social dynamics issues that emerge is the Work-Family Conflict; this is an effect that every employee feels like a form of social dynamics that occurs due to the implementation of WFH. Work-Family Conflict can be caused by having multiple roles in work and family. A strategy, therefore, is needed to overcome this. Commitment is one of the benchmarks for success for employees who can overcome any job dilemma. Therefore, employees who choose to be part of an organization (affective commitment) as opposed to those who believe they need to be part of it (continuous commitment) or those who feel obligated to be part of it (normative commitment) are willing to attempt to support their organization (Mitić et al., 2017) (Radosavljević et al., 2017).

One of the critical strategic resources for organizations is information technology because it can collect important information in making decisions. The phenomenon of information technology relates to the relationship between information technology, humans, and organizations from various perspectives. Also, Orlikowski (1991) in Terek et al. (2018) examined the impact of information technology on changes in control and organizational processes, and the results showed that information technology strengthens existing organizational forms and facilitates the intensification and fusion of existing control mechanisms (Terek et al., 2018).

One of the study results states that the mastery of information technology for an employee can affect performance: usability, convenience, behavioral attitudes, behavioral intentions, and behavior towards information technology (Handayani et al., 2018). Utilization of information technology appropriately accompanied by an employee's expertise in its operation can improve employee performance. Telaumbanua (2019) found that an organization's efficiency and productivity will increase if using technology appropriately. It is a challenge for an organizational leader to retain people when taking advantage of the very rapid advances and developments in technology in their business processes. For example, when computers using are an increasingly diverse range of applications, the perception arises that computer technology will narrow jobs for humans. Employers must show their commitment to compete and continue to improve their work abilities so that they can survive in an organization (Telaumbanua, 2019).

The above description concludes that the use of information technology has a positive or negative impact on commitment and performance. The higher the ability to use information technology, the higher the employee's commitment and performance, and conversely, the lower the ability to use information technology, the lower the employee's commitment and performance. $\mathbf{H}_{1}$ : Information technology utilization influence employee commitment $\mathbf{H}_{2}$ : Information technology utilization influence employee performance

Ahmad (2008) proposes that an individual's behavior is the expectations of other people's behavior (Ahmad, 2008). Kahn et al. (1964) in Christine et al. (2010) defined family-work conflict as a form of inter-role conflict in which the role pressures of the work and family environment do not match each other (Christine et al., 2010). Then such mismatch clearly shows by the fact that participation in work roles becomes more difficult based on participation in family roles and vice versa. Stone (2005) in Mubassyir \& Herachwati (2014) mentions that work-family conflict occurs 
because employees face problems distinguishing between home and works activities (Mubassyir \& Herachwati, 2014). There are two kinds of work-family conflict, 1) work conflict against family and 2) family conflict with work (Aboobaker et al., 2017), As shown by the more demands and pressures in family and work life, the lower one's performance, and occurs because the demands and pressures in a person's life from the dual roles played (as a worker and husband/wife) make the completion of one's work less maximal (Christine et al., 2010). The energy and time spent developing a career in work is an allocation of energy and time that sacrifices family life (Lathifah \& Rohman, 2016). Work-family conflict can be caused by having multiple roles in work and family. Some of the roles that can interfere with roles in work and roles in the family can be are: 1) reduced time with family due to work, 2) after work, energy and mind are very tired, 3) daily work done hastily, 4) the holiday schedule does not match with other family members, and 5) insensitivity to reduce work and increase the intensity of time with family (Christine et al., 2010).

Furthermore, Mubassyir \& Herachwati (2014) conducted a study entitled the effect of workfamily conflict on the performance of female nurses with the intervening variable of organizational commitment at the Bhakti Dharma Husada Hospital Surabaya, showing the results that directly the work-family conflict variable $(\mathrm{X})$ on the performance variable $(\mathrm{Y})$ had no significant effect, but the relationship is not directly variable work-family conflict $(\mathrm{X})$ to the performance variable $(\mathrm{Y})$ with variable organizational commitment $(\mathrm{Z1})$ as intervening variables showed a significant effect (Mubassyir \& Herachwati, 2014).

According to a literature review that exists, work-family conflicts positively or negatively affect commitment and performance in the opposite direction. The more the level of conflict, the smaller the commitment and employee performance, and conversely, the less conflict, the greater the commitment and employee performance.

$\mathbf{H}_{3}$ : Work-family conflict influence employee commitment

$\mathbf{H}_{4}$ : Work-Family conflict influence employee performance

Terek et al. (2018) explain that organizational commitment is a condition in which employee sides with an organization and have the goal and desire to survive (Terek et al., 2018). While Meyer \& Allen (1991), there are three main components in organizational commitment as follow: 1) affective commitment is an emotional relationship and an employee's involvement in the organization; 2) continuance commitment is the foundation of employee loyalty to the organization; 3) normative commitment is a feeling of employee responsibility to their obligations to the organization (Meyer \& Allen, 1991).

The organizational commitment referred to here is the employee's commitment to the organization, which express through the attitudes, views, sincerity, ability, and willingness of employees (Irfan, 2014). From the literature review above, we conclude commitment of an employee or individual to his organization has a positive or negative impact on the performance of the employee or individual.

There are still many experts with different points of view in defining performance. Performance measurement and management can be constrained if it is unable to define performance. Several studies have explained that performance is the appearance of an employee's work in quantity and quality. There is also an explanation that performance is the achievement of a person, unit, or division in carrying out tasks with their expertise and the standards set in organizational goals. According to Mulyadi (2007) in Irfan (2014), performance is the success of realizing strategic goals achieved by individuals, teams, or organizational units that have to predetermine the expected behavior (Irfan, 2014). Notoatmojo (2009) in Irfan 2014) defines performance as an ability to perform following his duties and functions (Irfan, 2014). Mangkunegara (2009) in Lathifah \& Rohman (2016) mentions that performance or work performance results from work achieved by an employee in carrying out his duties in quality and quantity according to his responsibilities (Lathifah \& Rohman, 2016). 
Employee performance is a complete display of the company's goals done by the employee in a particular period, which also shows the effect of the company's operations in utilizing existing resources. Bernadin and Russel (2000) in Mubassyir \& Herachwati (2014) explain six main criteria in measuring performance: 1) quality, 2) quantity, 3) timeliness, 4) cost-effectiveness, 5) need for supervisor, 6) interpersonal (Mubassyir \& Herachwati, 2014).

From there, performance define as a reflection of the results of the implementation of activities according to operational instructions, its duties, and functions on the expertise and skills possessed to achieve the targets or goals of both individuals and organizations and influence by employee commitment

H5: Employee commitment influence employee performance

\section{Research Method}

This research explores phenomena in the Main Inspectorate of the Ministry of Research and Technology/the National Research and Innovation Agency, where the author works. The population in this study was 158 employees of the Main Inspectorate of the Ministry of Research and Technology/the National Research and Innovation Agency. Regarding the data needs of this study, we use purposive sampling, which sampling on specific considerations (Telaumbanua, 2019).

The data collection tool used in this study was a questionnaire, in which data collection by making a list of questions given to respondents to be responded to or answered. The questionnaire using the application google form was distributed by sharing a link accompanied by a research data collection permit from the leader. To measure information technology, we adopt Ismail (2017), speed, consistency, accuracy, reliability (Ismail, 2017). While to measure work-family conflict, we adopt Christine et al. (2010), work affects the family, and family influences work. Then, to measure commitment, we adopt Meyer and Allen (1991), affective commitment, continuance commitment, normative commitment. As in final, to measure employee performance, we adopt Bernadine and Russel (2000), quality of work, quantity of work, timeliness, effectiveness, independence. The hypothesis in this study examines using the approach Structural Equation Model (SEM), which is processed using Partial Least Square (PLS). We explore our results of data collection through the measurement model and structural model.

\section{Results and Discussions}

To ensure that items test can truly be trusted to measure the phenomena proposed in the study, the researcher conducted a pre-research process, using SmartPLS involving 32 people to assess the 49 statements initially proposed. Of the 49 statements, then 11 statements were found not reliable but valid.

From pretest results, since the results are valid but unreliable, we decided to review and revise 11 statements as it resulted in outer loading < 0.6 . After we revised, we decided to distribute the surveys to 158 employees as respondents targeted, then after two weeks of the survey, we received 107 pieces of feedback, and at the end, only 104 respondents analyzed, since three responses did not respond. We believe that respondents play important role in every research results. Therefore, The data presented in this study also illustrates the purpose of this study, as shown in Table 1. 
Table 1. Respondents

\begin{tabular}{llc}
\hline Characteristics & & Total \\
\hline \multirow{4}{*}{ Marital Status } & Married & 75 \\
& Single & 29 \\
& Total & $\mathbf{1 0 4}$ \\
Gender & Male & 52 \\
& Female & 52 \\
& Total & $\mathbf{1 0 4}$ \\
& High School & 3 \\
Education Background & Diploma & 13 \\
& Undergraduate & 70 \\
& Postgraduate & 18 \\
& Total & $\mathbf{1 0 4}$ \\
& $<25$ Years & 2 \\
& 25 - 35 Years & 79 \\
Age Range & $36-55$ Years & 22 \\
& $>55$ Years & 1 \\
& Total & $\mathbf{1 0 4}$ \\
\hline
\end{tabular}

According to the Table above, this study reflects the majority of respondents who are married, the majority have a higher education background, and the majority are in the age range of 25 - 35 years, and there is no difference between male and female therefore gender will not be considered as part of our research discussion.

Items excluded or cleared in this comprehensive data validity test, only 5 statement. Compared with the results pretest which issued 11 statement items, the results of this comprehensive data test showed better results. From the results of the data processing, it is followed by checking the validity and reliability of the research variables. The results of the validity and reliability tests can be seen in Table 2 .

Table 2. Construct Reliability and Validity

\begin{tabular}{ccccc}
\hline Variable & $\begin{array}{c}\text { Cronbach's } \\
\text { Alpha }\end{array}$ & rho_A & $\begin{array}{c}\text { Composite } \\
\text { Reliability } \\
\text { (CR) }\end{array}$ & $\begin{array}{c}\text { Average Variance } \\
\text { Extracted } \\
\text { (AVE) }\end{array}$ \\
\hline $\begin{array}{c}\text { Commitment } \\
\text { Information }\end{array}$ & 0,843 & 0,846 & 0,882 & 0,517 \\
Technology Utilization & 0,912 & 0,916 & 0,929 & 0,619 \\
$\quad$ Performance & 0,957 & 0,959 & 0,962 & 0,571 \\
Work Family Conflict & 0,915 & 0,924 & 0,929 & 0,568 \\
\hline
\end{tabular}

From Table 2. indicates AVE value of all variables is more significant than 0.5. So it can be concluded that all the variable indicators of this study have met convergent validity. Besides that, the value composite reliability for all variables more significant than 0.70 . All variables are reliable. Comprehensive structural model validation is carried out using the Goodness of Fit (GoF) which is a combined measurement technique between the Measurement (Outer) model or 
measurement model test and the Structural (Inner) model or structural model test. GoF results are based on the value of R Square as shown in the following Table:

Table 3. R Square Value

\begin{tabular}{lll}
\hline & R Square & R Square Adjusted \\
\hline Commitment & 0.358 & 0.345 \\
Performance & 0.503 & 0.488 \\
\hline
\end{tabular}

From Table 3 above shows that the value of the influence of the performance variable is quite large, namely 50.3 percent, while the commitment is 35.8 percent. On the line of the relationship between the use of information technology and work-family conflict on organizational commitment, the resulting R-Square of 0.358 indicates that the percentage of diversity in responses regarding employee commitment expressed by the Main Inspectorate of the Ministry of Research and Technology/National Research and Innovation Agency can be explained by the use of information technology and work-family conflict $35.8 \%$, while the remaining $64.2 \%$ was explained by variables other than the use of information technology and work-family conflicts. Meanwhile, the R Square value for performance of 0.503 means that the large percentage of the performance which can be explained by the use of information technology and work-family conflict is $50.3 \%$, while the remaining $49.7 \%$ is explained by variables. other. To see the results of hypothesis testing in this study, it is shown from the results of the path coefficients in the following Table:

Table 4. Path Coefficients

\begin{tabular}{lll}
\hline & T Statistics & P Values \\
\hline ITU $\rightarrow$ EC & 1.708 & 0.088 \\
ITU $\rightarrow$ EP & 3,549 & 0.000 \\
WFC $\rightarrow$ EC & 5,883 & 0.000 \\
WFC $\rightarrow$ EP & 2.574 & 0.010 \\
EP $\rightarrow$ EP & 2.831 & 0.005 \\
\hline
\end{tabular}

From the data path coefficients above, it can be explained that the results of testing the hypothesis of this study that the use of information technology does not have a significant effect on the commitment of the employees of the Main Inspectorate of the Ministry of Research and Technology/National Research and Innovation Agency. For the results of other hypothesis testing between work-family conflict on employee commitment, use of information technology on employee performance, work-family conflict on employee performance, and employee commitment to employee performance, all have proven to have a significant effect. The results of this study also show an indirect effect between the variables of information technology use and work-family conflict variables on employee performance variables with employee commitment variables as anvariable intervening, as shown in Table 5. 
Table 5. Indirect Effects

\begin{tabular}{lll}
\hline & T Statistics & P Value \\
\hline ITU -> EC -> EP & 1.283 & 0.200 \\
WFC -> EC -> EP & 2.696 & 0.007 \\
\hline
\end{tabular}

From Table 5 above, it can be explained that commitment does not mediate the effect of the use of information technology on performance. This means that if employees of the Main Inspectorate of the Ministry of Research and Technology/National Agency for Research and Technology use information technology, this will affect employee performance but it has nothing to do with employee commitment to work. Employees will only use technology in the context of doing work. However, commitment mediates the effect of work-family conflict on performance. This means that work and family conflicts that are felt by employees of the Main Inspectorate of the Ministry of Research and Technology/National Research and Innovation Agency will affect employee performance and this is also due to employee commitment to work.

Information technology utilization is not proven to influence employee commitment; results show no support by analyzing the result. This result shows that the Main Inspectorate of the Ministry of Research and Technology/National Research and Innovation Agency has a high commitment to the organization regardless of the completeness of facilities or the use of existing information technology. Evidence of the commitment of the Main Inspectorate staff of the Ministry of Research and Technology/National Research and Innovation Agency from the average answers that are in the very high category.

These results are different from previous research conducted by Telaumbanua (2019), which shows that information technology has a positive and significant effect on work commitment and employee performance, while work commitment also has a positive and significant effect on performance. In addition, the results of research conducted by Terek et al. (2019) also show the results of information technology and organizational performance through the dimensions of job satisfaction and organizational commitment dimensions, which are statistically significant, strong, and positive.

Based on the information collected from respondents through questionnaires and situations that occurred when conducting the research, the difference in results was due to the previous research conducted in 2018 and 2019, which occurred in normal circumstances and was different from this research conducted during the Covid-19 pandemic. In addition, the population and research samples carry out in previous research at government agencies in the field of statistics and international scale private companies, which are closely related to information technology, in contrast to this research conducted in government agencies with the intensity of the need for the use of information technology not high.

Statements from survey instruments that met validity and reliability are: 1) job demands do not interfere with family life, 2) also, the more time spent on work time does not make it difficult to fulfill family responsibilities, 3) also, respondents can still do family activities, even though there are work demands, 4) although tired, does not make it difficult to fulfill family duties, 5) do not have to make changes to family activities even though there are work demands, 6) family demands do not conflict with work activities, do not have to delay doing some things while working even though at the same time there are demands for a time at home, 7) even though there are family demands, do not feel constrained when working, domestic life does not interfere with work responsibilities, 8) family problems do not hinder the ability to perform tasks at work. 
Work-family conflict influences employee commitment. This result shows that the increase or decrease in the work-family conflict variable affects the employee commitment variable. Therefore, the second hypothesis, which states that work-family conflict has a significant effect on employee commitment, is acceptable. Based on the study results, the commitment of the employees of the Main Inspectorate of the Ministry of Research and Technology/National Research and Innovation Agency, who became the respondents of this study, was influenced by conflicts that occurred in the work and family of employees.

These results confirm previous research conducted by Mubassyir \& Herachwati (2014) and Fauzia (2015), which show that the work-family conflict variable on the variable organizational commitment and work morale is significant. Mubassyir \& Herachwati (2014) mention the low role conflict faced by respondents in this study is because the respondent is in a safe zone with a working period of more than 2.5 years and is a civil servant so that the respondent works on his own will and will give best for the company. This research conduct in government agencies and the majority of respondents were civil servants and had a service period of more than 2.5 years. Fauzia (2015) also explained that the low role conflict faced by respondents overseas in Papua is high salaries so that family meets their needs and employees continue to show high enthusiasm or commitment to work to survive in the company (Fauzia, 2015).

To measure the use of information technology in this study, statement items that meet the value are external loadings used as follows: 1) the information technology used allows the employee to work at a more efficient pace, 2) the information technology used allows work at a more effective pace, 3 ) the information technology used makes work more consistently because there is a standard format, 4) The information technology used makes employees work more consistently because there are repetitions following the program's needs, 5) the information technology used can provide accurate information to follow the program run, 6) the information technology used can provide accurate information by detecting the slightest difference following the program run, 7) the information technology used can provide a sense of security in the work process, 8) the information technology used is reliable.

We conclude that the use of information technology has a positive and significant effect on employee performance. This result shows that the increase or decrease in the variable use of information technology is very influential on employee performance variables. Therefore, the third hypothesis, which states that information technology has a significant effect on employee performance, is accepTable. Based on the study results, the performance of the Main Inspectorate of the Ministry of Research and Technology/National Research and Innovation Agency, who was the research respondent, was strongly influenced by the use of information technology. This result shows that the employees of the Main Inspectorate of the Ministry of Research and Technology/National Research and Innovation Agency have good performance in the organization with complete facilities or use of existing information technology. Evidence of the high performance of the Main Inspectorate of the Ministry of Research and Technology/National Research and Innovation Agency from the average answers that are in the very high category.

These results reinforce previous studies referred to in this study, one of which is by Handayani (2018), which shows that mastery of information technology has a positive and significant effect on employee performance. Telaumbanua's (2019) statement confirms this result, which shows that information technology has a positive and significant effect on work commitment and employee performance. This argument explains that the mastery of information technology can affect performance, including usability, convenience, behavioral attitudes, behavioral intentions, and behavior towards information technology. Utilization of information technology appropriately accompanied by an employee's expertise in its operation can improve 
both organizational performance and employee performance. So it can be concluded that information technology directly affects the performance of its users, which in turn will also improve organizational performance. Of course, in the era of the industrial revolution 4.0, which is also called the digital era, which is increasingly highlighting advances in information technology, generally showing the need for information technology to improve performance in every line of modern life.

Work-family conflict influences employee performance. This result shows that the increase or decrease in the work-family conflict variable significantly affects the employee performance variable. Therefore, the fourth hypothesis, which states that work-family conflict has a significant effect on employee performance, is accepTable. Based on the study results, the performance of the Main Inspectorate of the Ministry of Research and Technology / National Agency for Research and Technology, who became the respondents of this study, was influenced by conflicts that occurred in the work and family of employees.

In contrast to research conducted by Mubassyir \& Herachwati (2014), which shows that the effect of work-family conflict variables on performance variables is insignificant, this result explains the need for success in work and the family causes minimum family-work conflicts. Respondents in the study showed good performance regardless of the conflicts that occurred in the family or work. The results in this study confirm previous research conducted by Christine et al. (2010), which states that family work conflicts positively affect performance. This result can be explained by mutual understanding in the family, making conflicts manageable to improve performance. As shown in the results of this research questionnaire, the low level of conflict that occurs shows that employees can manage conflicts in the family and work to improve employee performance.

The hypothesis state of employee commitment will influence employee performance, increasing or decreasing the commitment variable that significantly affects the employee performance variable. Therefore, the fifth hypothesis, which states that employee commitment significantly affects employee performance, is accepTable. Based on the results of the study, the performance of the Main Inspectorate of the Ministry of Research and Technology/National Research and Innovation Agency, who became the respondents of this study, was strongly influenced by each employee's commitment. This result shows that the employees of the Main Inspectorate of the Ministry of Research and Technology/National Agency for Research and Technology have good performance in organizations with high commitment, as shown by the average answers in the very high category.

These results confirm previous research conducted by Irfan (2014), which shows that organizational restructuring and organizational commitment have a significant effect on performance both partially and simultaneously. Moreover, Mubassyir \& Herachwati (2014) research shows significant results between organizational commitment and performance. It explains that the respondent is a civil servant so that the respondent works on his own will and will give the best for the organization. As happened in this study, the majority of respondents are civil servants.

\section{Conclusions}

From this study, we can conclude that the use of information technology does not significantly affect the commitment of the Main Inspectorate of the Ministry of Research and Technology / National Research and Innovation Agency. In contrast to previous studies showing a significant effect, this research visual another perspective compare with previous research. The 
results of another hypothesis testing between work-family conflict on employee commitment, use of information technology on employee performance, work-family conflict on employee performance, and employee commitment to employee performance all have proven to have a significant effect.

Outside of this research hypothesis, other information obtains that the effect of information technology on employee performance with the mediating variable by commitment is known to be insignificant. This result shows that if employees of the Main Inspectorate of the Ministry of Research and Technology / National Research and Innovation Agency use information technology, then this will affect employee performance but has nothing to do with employee commitment to work. Employees will only use technology in the context of doing work.

Furthermore, between work-family conflict on employee performance with a mediating variable by commitment which shows significant results and explains that work and family conflicts happen within employees of the Main Inspectorate of the Ministry of Research and Technology / National Research and Innovation Agency will affect employee performance, and this is also due to employee commitment to work.

\section{References}

Aboobaker, N., Edward, M., \& Pramatha, K. P. (2017). Work-family conflict, family-work conflict and intention to leave the organization: Evidences across five industry sectors in India. Global Business Review, 18(2), 524-536. https://doi.org/10.1177/0972150916668696

Ahmad, A. (2008). Job , Family and Individual Factors as Predictors of Work-Family Conflict. 4(June), 57-65.

Christine, W. S., Oktorina, M., \& Mula, I. (2010). Pengaruh konflik pekerjaan dan konflik keluarga terhadap kinerja dengan konflik pekerjaan keluarga sebagai intervening variabel (studi pada dual career couple di Jabodetabek). Jurnal Manajemen Dan Kewirausahaan, 12(2), 121-132. https://doi.org/10.9744/jmk.12.2.pp.

Dewett, T., \& Jones, G. R. (2001). The role of information technology in the organization: A review, model, and assessment. In Journal of Management (Vol. 27, Issue 3). https://doi.org/10.1016/S0149-2063(01)00094-0

Fauzia, F. (2015). Pengaruh Socio-Cognitive terhadap Work Family Conflict dan Pengaruhnya terhadap Semangat Kerja. http://repository.ut.ac.id/7556/.

Handayani, R., Runtuwene, R., \& Sambul, S. (2018). Pengaruh penguasaan teknologi informasi terhadap kinerja karyawan pada PT. Telkom Indonesia Cabang Manado. Jurnal Administrasi Bisnis, 6(2), 10-16.

Irfan, M. (2014). Analisis Pengaruh Restrukturisasi dan Komitmen Organisasi terhadap Kinerja Pegawai Dinas Pertanian Tanaman Pangan dan BP4K Kabupaten Sumbawa. http://repository.ut.ac.id/156/.

Ismail, F. (2017). Pengaruh Kompetensi Sumber Daya Manusia dan Penggunaan Teknologi Informasi terhadap Kualitas Pelayanan pada Kantor Layanan Operasional BPJS Kesehatan Kabupaten Berau. http://repository.ut.ac.id/7525/1/43091.pdf.

Lathifah, I., \& Rohman, A. (2016). The influence of work-family conflict on turnover intentions with job satisfaction as an intervening variable on public accountant firms in Indonesia. The Transformation of Cultural and Economic in Global Market Access, 154-162.

Meyer, J. P., \& Allen, N. J. (1991). A three-component conceptualization of organizational commitment. Human Resource Management Review, 1(1), 61-89. https://doi.org/10.1057/9780230501997_5

Mitić, S., Nikolić, M., Jancov, J., Vukonjanski, J., \& Terek, E. (2017). The impact of information technologies on commincation satisfaction and organizational learning in companies in 
Serbia. Dynamic Relatonships Management Journal. https://doi.org/10.1016/j.chb.2017.07.012

Mubassyir, A. H., \& Herachwati, N. (2014). Pengaruh work-family conflict terhadap kinerja perawat wanita dengan variabel intervening komitmen organisasional di RSUD Bhakti Dharma Husada Surabaya. Manajemen Teori Dan Terapan, 7(3), 143-162.

Radosavljević, Ž., Čilerdžić, V., \& Dragić, M. (2017). Employee organizational commitment. International Review, 9(1-2), 18-26. https://doi.org/10.5937/intrev1702018R

Siddiqui, M. N. (2014). Success of an organization is a result of employees performance. Advances in Social Sciences Research Journal, 1(4), 179-201. https://doi.org/10.14738/assrj.14.280

Telaumbanua, E. (2019). Pemanfaatan teknologi informasi terhadap komitmen kerja dan kinerja pegawai Badan Pusat Statistik Kabupaten Nias. Jurnal Akuntansi Dan Manajemen PEMBNAS, 6(1), 19-30.

Terek, E., Mitić, S., Cvetkoska, V., Vukonjanski, J., \& Nikolić, M. (2018). The influence of information technology on job satisfaction and organizational commitment. November. https://doi.org/10.17708/DRMJ.2018.v07n02a04

Zeidner, M. (2020). "Don't worry-be happy": The sad state of happiness research in gifted $\begin{array}{llll}\text { students. High } & \text { Ability }\end{array}$ https://doi.org/10.1080/13598139.2020.1733392 